\title{
ANTIHYPERGLYCEMIC ACTIVITY OF IMPERATA CYLINDRICA ROOT METHANOL EXTRACT IN
} RATS

\author{
RUSLIN $^{1 *}$, VICA ASPADIAH ${ }^{1}$, DIAH DHIANAWATY2 \\ 1Faculty of Pharmacy, Halu Oleo University, Kendari, Southeast Sulawesi, Indonesia, ${ }^{2}$ Biochemistry and Biomolecular Laboratory, Medical \\ Faculty, Padjadjaran University, Bandung, West Java, Indonesia
}

Email: mahaleo241@yahoo.co.id

Received: 25 Jan 2020, Revised and Accepted: 23 Mar 2020

\section{ABSTRACT}

Objective: This study aims to evaluate the inhibitory activity of Imperatacylindrica root methanol extract on glucose absorption level in intestine of male Wistar strain rats at a dose of $90 \mathrm{mg} / \mathrm{kg}-\mathrm{bw}$, which is a dose having antihypertensive activity.

Methods: Extract inhibitory activity on the glucose absorption level in the intestine of the rats followed Soedigdo-Marsongkohadi method. Glucose absorption level was measured from a mixture of 30 mmol glucose in $0.9 \%$ sodium chloride solution as the control solution and a mixture of the extract at the dose of $90 \mathrm{mg} / \mathrm{kg}$-bw in another control solution as the tested solution

Results: The result showed that the extract at the dose of $90 \mathrm{mg} / \mathrm{kg}$-bw had significant activity (p<0.05) to decrease the glucose absorption level in the intestine of the rats.

Conclusion: I. cylindrica root methanol extract at the dose of $90 \mathrm{mg} / \mathrm{kg}$-bw had a significant activity to inhibit the glucose absorption level in the intestine of the rats. Thereby, the extract at the dose of $90 \mathrm{mg} / \mathrm{kg}$-bw had antihyperglycemic activity.

Keywords: Antihyperglycemic, Cogongrass, Glucose absorption, I. cylindrical

(C) 2020 The Authors. Published by Innovare Academic Sciences Pvt Ltd. This is an open access article under the CC BY license (http://creativecommons.org/licenses/by/4.0/) DOI: http://dx.doi.org/10.22159/ijcpr.2020v12i3.38324. Journal homepage: https://innovareacademics.in/journals/index.php/ijcpr

\section{INTRODUCTION}

Imperata cylindrical (I. cylindrical), although as one of the top 10 worst invasive weeds in the world, is considered as an herb in Asia. Indonesian people use the roots [1-3]. I. cylindrica root was reported containing many phytochemicals such as salicin; 1- $(3,4,5$ trimethoxyphenyl)-1,2,3-propanetriol; 1-0-p-coumaroylglycerol; 4 methoxy-5-ethylcoumarin-7-0- $\beta$-D-glucopyranoside; 6-hydroxy-5methoxyflavone; 5-methoxyflavone; 5,7-dihydroxy-8-methoxyflavone; 4'-methoxyflavone-6- $O-\beta$-D-glucopyranoside, etc [4], Isoeugenin (7-hydroxy-5-methoxy-2-methylchromone),ferulic acid, p-coumaric acid and caffeic acid [5]. I. cylindricaroots are used as traditional medicine for hypertension treatment in Southeast Sulawesi, Indonesia. It is also useful for the medication of several diseases, including edema, fever, and jaundice [1-3]. Ruslin, proved that I. cylindrica root methanol extract grown in Kendari (Southeast Sulawesi) at the dose of 60 and $90 \mathrm{mg} / \mathrm{kg}$-bw have significant activity as antihypertensive in male Wistar strain rats [3].

The polyphenol compounds in methanol extract of I. cylindrica root antioxidant activity, which wasIC ${ }_{50}$ of $0.32 \mathrm{mg} / \mathrm{ml}$ along with the ability to donate a hydrogen atom to 1,1-diphenyl-2-pikrilhidrazil (DPPH) free radical, a total polyphenol content of $1.53 \%$ gallic acid equivalent (GAE) [6], and a total flavonoid content of $1.17 \%$ quercetin equivalent (QE) [7]. Isoeugenin (new chromone) in methanol extract of $I$. cylindrical root as a nitric oxide synthase inhibitor is known to have a potential treatment for iflammatory disease [5], and it is also used for liver disease in ethnomedicinal plant [8]. The methanol extract is regarded as antianthelmintic at a concentration of $80 \mathrm{mg} / \mathrm{ml}$ and can cause paralysis in $3.3 \mathrm{~min}$ and death in $6.0 \mathrm{~min}$. The potent activity of antianthelmintic is indicated by the presence of various phytoconstituents such as tannins and saponins [9]. The methanol extract at the doses of 100, 200 and 300 $\mathrm{mg} / \mathrm{kg}$, p. o had anticoagulant activity in rats [10]. The aqueous extract of $I$. cylindrical aerial part has very potent antibacterial activity comparatively with the ether and ethanol extracts when tested against Staphylococcus aureus and Escherichia coli [11]. However, the root extract which is different from in the extraction method, solvent and dose does not have an effect to $S$. aureus (ATCC
6538P), Bacillus subtilis (ATCC 6633), Pseudomonas aeruginosa (ATCC 9027), Mycobacterium smegmatis (ATCC 14468), Candida albicans (ATCC 2091) [12].

Indonesian people still use traditional medicine; one of the four types of traditional medicine is jamufrom herbs. Jamu is considered as natural-based medicines, which can be processed as herbmedicines [13]. Double burden of communicable and noncommunicable diseases increase in Indonesia and become main attention for the government. Hypertension, diabetes mellitus, cancer, and chronic obstructive pulmonary diseases are primary non-communicable disease-causing worldwide mortality, enhance the risk of strokes, heart attacks, and kidney failure, which become serious problems globally. World Health Organization (WHO) classified the main types of noncommunicable diseases (NCDs); they are cardiovascular diseases (such as heart attacks and stroke), cancers, chronic respiratory diseases (such as chronic obstructive pulmonary disease and asthma) and diabetes [14-16].

The data reported by the WHO in 2017, eighty-six diseases of most causing deaths were discovered in Indonesia. Among those diseases, stroke is regarded as the major cause of deaths. Meanwhile, coronary heart disease (CHD), diabetes mellitus (DM), and hypertension were $2^{\text {nd }}, 3^{\text {rd }}$ and $16^{\text {th }}$ respectively of the top 86 diseases, which cause deaths. Total deaths in Indonesia caused by the 86 diseases could be ranked in the following: stroke caused 332,663 deaths; CHD caused 259,738 deaths; DM caused 104,099 deaths, and hypertension caused 25,868 deaths [17].

\section{MATERIALS AND METHODS}

\section{Preparation of materials}

I. cylindricaroot methanol extract was extracted from I. cylindrica that has grown in Kendari (Southeast Sulawesi)., glucose test reagent and trichloroacetic acid (TCA) 8\% (St. Reagensia), anaesthetic drug: KTM-100 injection (Guardian Pharmatama), spectrophotometer Eppendorf Biospectrometer Basic AG 22331 Hamburg seri: 6135BJ Balance: Sartorius 2442. Perfusion equipment was designed by P. Soedigdo and Marsongkohadi, glass equipment, 
surgery equipment, micro pipette (CAPP), micro tube, syringe with needle $(5 \mathrm{ml}$ and $10 \mathrm{ml})$ and Wistar strain rats which had $170-200 \mathrm{~g}$ weight taken from the School of Pharmacy, Institut Teknologi Bandung.

\section{Experimental procedures}

The protocol of the study was approved by the Animal Ethics Committee of Faculty of Medicine, Universitas Kristen Maranatha-R. S. Immanuel on No. 193/KEP/IV/2018 on 7 April 2018. Perfusion method used was a method described by Soedigdo-Marsongkohadi [18]. Before the examinations, all Wistar strain rats were placed in the laboratory for seven days. The rats were occupied in a suitable environment with several provided facilities such as normal temperature of the living room, a 12-hour of darkness/12-hour of light cycle, and food and water.

KTM-100 injection was injected via an intramuscular (IM) route to anaesthetize the rats at the dose of $0.4 \mathrm{ml} / 200 \mathrm{~g}$-bw. After the rats under anesthetized state, the abdomen of the rats was opened and the perfusion instrument was put in the intestine where both intestine in abdomen and perfusion instrument were linked by two bent pipettes. The first pipette used was $10 \mathrm{~cm}$ placed from the pylorus, and the second pipette was $25 \mathrm{~cm}$ placed from the first pipette. Then the intestine was cleaned by $0.9 \%$ sodium chloride solution. Afterward, the control solution was circulated in the intestine four times per minute. The glucose level in the control solution was measured every 15 min for one hour. After one hour, the control solution was thrown out from the intestine; therefore, a repeated clean of the intestine was performed by $0.9 \%$ sodium chloride solution.

Then, the inhibitory activity measurement of the extract on glucose absorption considered as the tested solution. The tested solution was circulated again in the intestine of the rats and the glucose level in the tested solution was measured every $15 \mathrm{~min}$ for one hour. Unabsorbed glucose level was measured by spectrophotometer at wavelength 505 $\mathrm{nm}$ while absorbed glucose level was calculated from the unabsorbed glucose level by using the equation: the absorbed glucose levels = (100-unabsorbed glucose level) (\%).

\section{RESULTS AND DISCUSSION}

The glucose absorption level from glucose control and a mixture of glucose and I. cylindrical root methanol extract at the dose 90 $\mathrm{mg} / \mathrm{kg}$-bw (as glucose tested solution) by the intestine of the rats was measured in 15, 30, 45 and 60 min has shown in table 1 and table 2 .

Table 1: Result of the glucose absorption level measurement by the intestine of the rats from glucose solution (control) and a mixture solution of glucose with I. cylindrical root methanol extract at the dose of $90 \mathrm{mg} / \mathrm{kg}$-bw (glucose tested)in 15, 30, 45 and $60 \mathrm{~min}$ at the wavelength of $435 \mathrm{~nm}$

\begin{tabular}{|c|c|c|c|c|}
\hline \multirow[t]{2}{*}{ No. rat } & \multirow[t]{2}{*}{ Bodyweight (g) } & \multirow[t]{2}{*}{ Time of glucose absorption (min) } & \multicolumn{2}{|c|}{ Glucose absorption level (\%) } \\
\hline & & & Control & Tested \\
\hline \multirow[t]{5}{*}{1} & 189 & 15 & 45.45 & 46.10 \\
\hline & & 30 & 56.14 & 48.33 \\
\hline & & 45 & 56.51 & 52.42 \\
\hline & & 60 & 63.95 & 53.91 \\
\hline & & Average & 55.51 & 50.19 \\
\hline \multirow[t]{5}{*}{2} & 173 & 15 & 57.36 & 37.36 \\
\hline & & 30 & 60.00 & 44.16 \\
\hline & & 45 & 64.53 & 42.65 \\
\hline & & 60 & 70.76 & 47.17 \\
\hline & & Average & 63.16 & 42.84 \\
\hline \multirow[t]{5}{*}{3} & 196 & 15 & 59.15 & 37.81 \\
\hline & & 30 & 59.46 & 46.65 \\
\hline & & 45 & 61.90 & 51.53 \\
\hline & & 60 & 65.86 & 52.44 \\
\hline & & Average & 61.59 & 47.11 \\
\hline \multirow[t]{5}{*}{4} & 172 & 15 & 63.42 & 60.37 \\
\hline & & 30 & 63.42 & 61.59 \\
\hline & & 45 & 64.94 & 62.81 \\
\hline & & 60 & 65.86 & 62.81 \\
\hline & & Average & 64.41 & 61.90 \\
\hline \multirow[t]{5}{*}{5} & 196 & 15 & 54.86 & 38.81 \\
\hline & & 30 & 55.98 & 39.18 \\
\hline & & 45 & 57.09 & 41.80 \\
\hline & & 60 & 58.96 & 46.27 \\
\hline & & Average & 56.72 & 41.52 \\
\hline
\end{tabular}

Table 2: Result the glucose absorption level measurement by the intestine of the rats from glucose solution (control) and a mixture solution of glucose with Imperatacylindrica root methanol extract at the dose $90 \mathrm{mg} / \mathrm{kg}$-BW (glucose tested) in $1 \mathrm{~h}$

\begin{tabular}{lll}
\hline No. of sample & Glucose absorption level (\%) \\
\cline { 2 - 3 } & Control solution & Imperatacylindrica solution \\
\hline 1 & 55.51 & 50.19 \\
2 & 63.16 & 42.82 \\
3 & 61.59 & 47.11 \\
4 & 64.41 & 61.90 \\
5 & 56.72 & 41.52 \\
mean \pm SEM & $60.28 \pm 3.33$ & $48.71 \pm 5.87$ \\
\hline
\end{tabular}

The table showed the absorption summary of glucose level from glucose control and glucose tested solution by the intestine of the rats occurred in 1 hour (h). The glucose absorption level in 1 hour from glucose control was 55.51; 63.16; 61.59; 64.41; and 56.72\% respectively and from glucose tested solution was $50.19 ; 42.84$; 47.11; 61.90; and 41.52\%, respectively. The results showed glucose 
absorption level decrease in the intestine of the rats was caused by $I$. cylindrical root methanol extract at the dose $90 \mathrm{mg} / \mathrm{kg}$-bw and the Student T-test between differences of the glucose absorption level from glucose solution (control) $(60.28 \pm 3.33 \%)$ and a mixture of glucose and I. cylindrical root methanol extract solution at the dose of $90 \mathrm{mg} / \mathrm{kg}-\mathrm{bw}(48,71 \pm 5.87 \%)$ were statistically significant $(\mathrm{p}<0.05)$.

Breakdown of food in the digestive system involves ingestion, digestions, then food absorption across the gastrointestinal epithelium prior to circulatory vessels occurs. In the gastrointestinal tract, nutrients are digested and net nutriome (is a term referring to all beneficial food components) is produced. Nutriome will be absorbed in the gastrointestinal tract and the main absorptive tissue in the gastrointestinal tract is the small intestine [19]. Based on the data in table 1 and 2 , the study showed that the glucose absorption occurred in the intestine by using I. cylindrica root methanol extract at the dose of $90 \mathrm{mg} / \mathrm{kg}$-bw(48.71 $\pm 5.87 \%)$. The result of glucose absorption level by the intestine of the rats determined glucose absorption level of control solution was $60.28 \pm 3.33 \%$ and the glucose absorption level of the tested solution was $48.71 \pm 5.87 \%$ and student T-test between differences of glucose control and glucose tested showed significant results $(p<0.05)$. This finding reveals $I$. cylindrical root methanol extract at the dose of $90 \mathrm{mg} / \mathrm{kg}$-bw has inhibitory activity on glucose absorption in the intestine.

The effect of chronic high glucose concentrations causes injuries of a large number of organs and tissues. As various reactions occurring inside the cells, in this worse condition, most of the cells can adjust the rate of intracellular glucose transport and can eliminate negative effects to the intracellular environment. Other cells which are susceptible to this effect include endothelial, neuronal, and $\beta$-cells [20]. Chronic hyperglycemia is a hallmark of diabetes mellitus and becomes a main risk factor for endothelial dysfunction and vascular complication. Vascular complications exhibit hyperinsulinemia due to compensation for insulin resistance associated with atherogenic risk (e. g., dyslipidemia, hypertension, procoagulant state) [20,21]. Endothelial cells release diverse mediators which affect the vascular tone (the balance of blood vessel as follows: vasoconstrictors such as endothelin-1, vasodilators such as nitric oxide), cell adhesion, and the homeostasis of clotting; and fibrinolysis [20-23]. Hyperglycemia disturbs cellular homeostasis and biochemistry, causing modifications both in small blood vessels (microvasculature) and large vessels (macro vasculature). Loss of normal function of ECs is marked by the following features: decreased endothelium-mediated vasorelaxation, deficiency in bioavailable nitric oxide (NO), deregulation of hemodynamic, and among others [20-23].

Vascular relaxation mechanism contributed by NO; the NO is generally produced by endothelial nitric oxide synthase (eNOS) towards vascular smooth muscle cells (SMC) to excite soluble sGC (soluble guanylyl cyclase) and producing the formation of cyclic guanosine monophosphate (cGMP). cGMP will activate protein kinase G (PKG), PKG can cause of vascular relaxation [21, 22]. Chronic hyperglycemia can cause diabetes mellitus (DM). Hyperglycemia in DM may develop vascular complications such as dyslipidemia, hypertension, retinopathy, neuropathy, and nephropathy, and others [20-23]. Severe impacts of chronic hyperglycemia have been described previously in this study. Therefore, the inhibitory activity on the glucose absorption in the intestine by using I. cylindrica root methanol extract at the dose of $90 \mathrm{mg} / \mathrm{kg}$-bwis useful to maintain health. The extract at the dose of $90 \mathrm{mg} / \mathrm{kg}$-bw can decrease the postprandial blood glucose level. The antihyperglycemic activity can prevent the development of other severe diseases or complications with severe diseases in DM such as hypertension. Besides, the extract also has anti-hypertensive activity on hypertension rat model; thereby, of I. cylindrica root methanol extract at the dose of $90 \mathrm{mg} / \mathrm{kg}$-bw has two synergistic activities as anti-hyperglycemic and anti-hypertensive.

\section{CONCLUSION}

The I. cylindrical root methanol extract at the dose of $90 \mathrm{mg} / \mathrm{kg}$-bw has been proved to have inhibitory activity on glucose absorption in the intestine of the rats. At the dose of $90 \mathrm{mg} / \mathrm{kg}$-bw (the antihypertensive dose) of I. cylindrica root methanol extract have significant activity $(\mathrm{p}<0.05)$ to inhibit the glucose absorption level in the intestine of the rats. Thereby, I. cylindrica root methanol extract at the dose of $90 \mathrm{mg} / \mathrm{kg}$-bw has antihyperglycemic activity.

\section{ACKNOWLEDGMENT}

We want to say thanks to Halu Oleo University, who give us supports and facilities for this research.

\section{FUNDING}

Nil

\section{AUTHORS CONTRIBUTIONS}

All the authors have contributed equally.

\section{CONFLICT OF INTERESTS}

The authors declare no conflicts of interest.

\section{REFERENCES}

1. Chiang YC, Tsai CC, Hsu TW, Chou CH. Characterization of 21 microsatellite markers from cogongrass, Imperata cylindrica (Poaceae), a weed species distributed worldwide. Am J Bot 2012;99:e428-30.

2. Dhianawaty DD. Study of plant ethnopharmacology to cure the bladder stones disease. In: Soemadji AA, Garna $\mathrm{H}$, Setiabudiawan B. ed. Traditional Medicine for the Treatment of Kidney Stone-Bladder Stones Diseases. Jatinangor: Universitas Padjadjaran Press; 2016. p. 24-7.

3. Ruslin, Asmawi MZ, Rianse U, Sahidin I, Dhianawaty D, Soemardji AA, et al. Anti-hypertensive activity of Alang-Alang (Imperata cylindrica (L.) beauv. root methanolic extract on male Wistar rat. Int J Res Pharm Sci 2013;4:537-42.

4. Subramaniam S, Sivasubramanian A. Tradition to therapeutics: sacrificial medicinal grasses desmostachya bipinnata and Imperata cylindrica of India. Bol Latinoam Caribe Plant Med Aromat 2015;14:156-70.

5. An HJ, Nugroho A, Song BM, Park HJ. Isoeugenin, a novel nitric oxide synthase inhibitor isolated from the rhizomes of imperata cylindrica. Molecules 2015;20:21336-45.

6. Dhianawaty D, Ruslin. Total polyphenol content and antioxidant activity of methanol extract of imperata cylindrica (L) Beauv.(Alang-alang) root. Majalah Kedokteran Bandung Mkb Bandung Med J 2015;47:60-4.

7. Dhianawaty DD, Ruslin, Syamsunarno MRAA, Hamimah H. The $54^{\text {th }}$ national seminar of Indonesia medicinal plants. In: Masfria, Agustama, Hasibuan PAZ, Khairunnisa, Mariane, Sitorus P, et al. ed. Total Flavonoid Content of Methanol Extract of I. cylindrica (L) Beauv. (Alang-alang). Medan: North Sumatera University; 2018. p. 36.

8. Dutt R, Pushpan R, Kumari H, Nishteswar K. Cirrhosis of livercare by indigenous and folk herbal medicine. Int Res J Pharm 2012;3:1-3.

9. Parvathy NG, Padma R, Renjith V, Rahate KP, Saranya TS. Phytochemical screening and anthelmintic activity of methanolic extract of imperata cylindrica. Int J Pharm Pharm Sci 2012;4:232-4.

10. Ojha SN, Nagore DH, Ganu GP. In vitro and in vivo anticoagulant activity of I. cylindrical a novel anticoagulant lead from natural origin. Phcog Net 2010;2:38-43.

11. Parkavi V, Vignesh M, Selvakumar K, Muthu JM, Joysa JR. Antibacterial activity of aerial parts of Imperata cylindrica (L) beauv. Int J Pharm Sci Drug Res 2012;4:209-12.

12. Chan LW, Cheah EL, Saw CL, Weng W, Heng PW. Antimicrobial and antioxidant activities of cortex magnoliae officinalis and some other medicinal plants commonly used in South-East Asia. Chin Med 2008;3:15.

13. Nurhayati N, Widowati L. The use of traditional health care among Indonesian Family. Health Sci J Indonesia 2017;8:30-5.

14. Regulation of The Minister of Health of Republic Indonesia Number 39 Y 2016 Concerning Guidelines for Healthy Program Implementation with Family Approach. Available from: 
http://www.depkes.go.id/resources/download/lain/PMK_No. 39_ttg_PIS_PK. pdf. [Last accessed 20 Mar 2018]

15. Strategic Plan of Ministry of Health in 2015-2019; 2015 Available from: http://www.depkes.go.id/resources/ download/ info-publik/Renstra-2015.pdf. [Last accessed on 20 Mar 2018]

16. World Health Organization. Noncommunicable diseases: more about noncommunicable diseases; 2018. Available from: www.who.int $>$ News $>$ Fact sheets. [Last accessed 09 Jun 2018]

17. World Life Expectancy Health Profile: Indonesia; 2017. Available from: http://www.worldlifeexpectancy.com/worldhealth-rankings. [Last accessed 09 Mar 2018].

18. Dhianawaty D, AMS SS. Effect of curcuma longa l. rhizome decoct on glucose absorption level in Intestine of male rat of wistar strain. Int J Pharm Pharm Sci 2014;6:532-5.
19. Epriliati I, Ginjom IR. Bioavailability of phytochemicals. Phytochemicals-a global perspective of their role in nutrition and health, Rao V. ed. InTech, Rijeka, Croatia; 2012. p. 401-28.

20. Marcovecchio ML. Complications of acute and chronic hyperglycemia. US Endocrinol 2017;13:1-17.

21. Popov D. Endothelial cell dysfunction in hyperglycemia: phenotypic change, intracellular signaling modification ultrastructural alteration, and potential clinical outcomes. Int J Diabetes Mellitus 2010;2:189-95.

22. Zhao Y, Vanhoutte PM, Leung SW. Vascular nitric oxide: Beyond eNOS. J Pharmacol Sci 2015;129:83-94.

23. Rajendran $P$, Rengarajan $T$, Thangavel J, Nishigaki $Y$, Sakthisekaran D, Sethi G, et al. The vascular endothelium and human diseases. Int J Biol Sci 2013;9:1057. 